\title{
Task-Based Language Learning and Student Motivation in Vocabulary Acquisition
}

\author{
Le Ngoc Thanh \\ Vinh Long Community College, Vietnam \\ Nguyen Buu Huan \\ Can Tho University, Vietnam
}

\begin{abstract}
This article explores the impact of task-based language learning on motivating non-English majors to acquire vocabulary at a community college in Vietnam. An experimental study was used to investigate the effectiveness of the use of text-based tasks to enhance students' vocabulary. The quantitative analysis used data from a questionnaire and vocabulary tests to examine students' motivation in vocabulary learning over twelve weeks. The qualitative analysis from follow-up interviews with students examined their attitudes towards the use of text-based tasks in terms of task-based language learning. The findings indicated that the participants were motivated to learn vocabulary and their vocabulary achievement improved after the experiment. Suggestions for language teachers to make better use of this approach are also discussed.
\end{abstract}

Vocabulary is viewed as a major part of language proficiency as it allows learners to use four language skills: listening, speaking, reading, and writing (Richards \& Renandya, 2002). This importance is recognised whether the language in question is a first, second, or foreign language (DeCarrico, 2001). However, many students at the community college level in Vietnam lack the vocabulary needed in many real-life situations, for example, at job interviews. This may be due to poor motivation, insufficient practice, and ineffective ways of learning vocabulary. Forty-eight percent of second-year students and $51 \%$ of first-year students at the community college in this study scored below five points out of ten on a vocabulary test at the beginning of the second semester. It could therefore be argued that the traditional vocabulary teaching technique in use, to some extent, was not an effective way to help students to communicate in English. Hence, it was important for the teachers of English at this college to stimulate students to learn vocabulary to improve the students' vocabulary gain. A different approach in teaching vocabulary to arouse students' interest in learning vocabulary needed to be considered.

The effects of task-based learning (TBL) in teaching English as a foreign language (EFL) classes have been addressed in the literature by a wide range of research. Studies have shown that 
tasks can be used in vocabulary classes to enhance learner motivation and vocabulary gain (de la Fuente, 2006; İlïn, İnözü, \& Yumru, 2007; Joe, 1998; Kavaliauskienė, 2005; Prabhu, 1987; Ruso, 2007). However, there had not been any empirical research in this field at the community college level in Vietnam. In particular, at the community college in this study, the TBL approach had not been used in English classes or with vocabulary learning. Therefore, this research aimed to utilise the task-based approach to engage students in learning vocabulary.

\section{Theoretical Framework}

This section reviews the literature on three concepts that are critical to motivating students to learn vocabulary: task-based learning and task, motivation, and vocabulary acquisition.

\section{Task-Based Learning and Task}

Willis (1996) argues that TBL combines communicative language use with a focus on language form. Thus, this approach is likely to provide learners with opportunities to connect old knowledge to other learning tasks in a communicative way (Ellis, 2003).

A number of definitions of task have been suggested (Bygate, Skehan, \& Swain, 2001; Nunan, 1989; Prabhu, 1987; Willis, 1996). However, this study draws on the definition of task by Willis (1996): a task is "[an activity] where the target language is used by the learner for a communicative purpose (goal) in order to achieve an outcome" (p. 23). This definition suggests the idea that tasks can bring learners to the meaningful use of a foreign language because language use is more important than language practice (Nunan, 2004). Activities involve the learners in completing the tasks assigned. The end product or the learning outcome may be linguistic, for example, an answer to a question, or non-linguistic, for instance, asking for directions to get to a particular place.

In addition, Ellis (2003) indicates five task features. First, a task is an activity in teaching and learning a language. This type of activity requires learners to use the target language to achieve a particular purpose. Second, a task focuses on meaningful activities or on the language form. Third, a task involves language use in terms of communication, to allow learners opportunities to take part in meaningful interactions to complete a specific assignment. Fourth, a task uses one or more language skills. Fifth, a task involves learners in understanding the use of the target language.

In this paper, tasks are described as text-based tasks. According to Willis (1996), text-based tasks use texts as a starting point. Texts in this study specifically refer to the reading texts in the English KnowHow Opener course book, which is currently used at the community college in this study. Willis (1996) further mentions that texts allow learners to use the target language; thus, with text-based tasks, learners must interpret the meanings within the text. Based upon Willis' (1996) framework of TBL, the text-based lessons designed for the experiment include pre-task (before the reading), in-task (while reading), and post-task (after the reading) tasks. Willis' (1996) framework has three stages: pre-task, task cycle, and language focus, which are shown in Figure 1. 


\section{Pre-Task}

Teacher

explores the topic

Students

note down useful words and phrases, spend time preparing for the individual task

\section{Task Cycle}

\begin{tabular}{|c|c|c|}
\hline Task & Planning & Report \\
\hline $\begin{array}{c}\text { Students } \\
\text { do the tasks in pairs or small } \\
\text { groups } \\
\text { Teacher }\end{array}$ & $\begin{array}{c}\text { Students } \\
\text { present reports }\end{array}$ \\
$\begin{array}{c}\text { monitors and encourages } \\
\text { communication }\end{array}$ & prepare to report to the class \\
provides language advice & $\begin{array}{c}\text { Teacher } \\
\text { acts as a chairperson and } \\
\text { provides feedback }\end{array}$ \\
\hline
\end{tabular}

\section{Language Focus}

\begin{tabular}{|c|c|}
\hline Analysis & Practice \\
\hline $\begin{array}{c}\text { Students } \\
\text { examine and discuss features of the text } \\
\text { enter new words or phrases } \\
\text { Teacher } \\
\text { reviews and analyses the activity }\end{array}$ & $\begin{array}{c}\text { Teacher } \\
\text { Students } \\
\text { practice the task }\end{array}$ \\
\hline
\end{tabular}

Figure 1. Willis' (1996) TBI framework

\section{Motivation}

Ellis (2003) suggests that the task-based approach brings a variety of benefits to learners; one of the most important is motivation. Motivation is therefore likely to be seen as the key to all learning. Once students are motivated, they can complete the given tasks or desired goals (Brophy, 2005).

Gardner and Lambert (1972), who grounded motivation research in a social psychology framework, introduced instrumental motivation, which refers to the learner's desire to learn a language for utilitarian purposes (such as employment, travel, or exam purposes) in the context of language learning, and integrative motivation, which refers to the desire to learn a language to integrate successfully into the target language community. Deci and Ryan (1985) classified motivation into two different categories: intrinsic and extrinsic. This paper focuses on intrinsic motivation, which is concerned with the internal incentive to do things for one's satisfaction (Deci \& Ryan, 1985; Lepper \& Malone, 1987).

According to Lepper and Malone (1987), seven factors promote intrinsic motivation: four individual factors (challenge, curiosity, control, and fantasy) and three interpersonal factors (competition, cooperation, and recognition). Individual factors are associated with what students are doing in their own efforts. Interpersonal factors play a role only when students are interacting with others. Thus, intrinsic motivation allows students to experience a sense of selfdetermination (Deci \& Ryan, 1985) and responsibility for their learning. 


\section{Vocabulary Acquisition}

Vocabulary acquisition is viewed as an integral part of language teaching and learning, especially in learning a foreign language (Huckin \& Coady, 1999). There are two main approaches to vocabulary acquisition: explicit learning and incidental learning (Schmitt, 2000). Explicit learning focuses on word study (Schmitt, 2000) and incidental learning involves more use of language than the learning itself (Richards \& Schmidt, 2002). Both types of learning are important and interrelated (Schmitt, 2000). This study particularly focuses upon incidental vocabulary learning, because it is seen as a by-product of reading and listening in and outside the classroom context (Huckin \& Coady, 1999). Thus, this type of learning includes both receptive and productive vocabulary (Ahmad, 2011; Nation, 2001). Nation (2001) also suggests three processes of mastering vocabulary: noticing (formal instruction), retrieving, and generating (learner-based). These processes highlight the cognate relationships between the target language and mother tongue and provide exposure to the language and background knowledge of vocabulary (Gass, 1999), all of which influence vocabulary learning. Other factors that may promote vocabulary gain include topic familiarity, time spent on learning, level of intake, and lexical retention (Pulido, 2004). From these perspectives, vocabulary learning in this study is focused on a process of integrating text-based tasks with language skills.

This review has considered the literature of task-based learning, motivation, and vocabulary acquisition. The review also highlighted the importance of the use of tasks relevant to this study. Thus, the research aimed to investigate the impacts of text-based tasks on motivating students to learn vocabulary. The research principally helped English language teachers gain insights into text-based tasks that effectively encourage students to develop their vocabulary knowledge. The research attempted to answer two questions:

1. To what extent do text-based tasks motivate non-English majors to acquire vocabulary and enhance their vocabulary acquisition?

2. What are students' attitudes towards the use of text-based tasks in vocabulary class sessions?

\section{Methodology}

The study used a two-group pre-test and post-test design, considering TBL as the independent variable, whereas students' motivation in vocabulary learning and students' vocabulary acquisition were two dependent variables. Text-based tasks based on Willis' (1996) framework were implemented. A questionnaire on intrinsic motivation was administered to investigate students' motivation in vocabulary learning before and after the experiment. The vocabulary pre-test and post-test specifically aimed to measure students' vocabulary acquisition.

Individual interviews on students' attitudes towards TBL were conducted after the experiment. Four analytical tests (scale tests, descriptive statistic tests, independent samples t-tests and paired samples t-tests) were computed to analyse and interpret the data.

\section{Participants}

Seventy-six freshmen (48 females, 28 males) in non-English majors at Vinh Long Community College in Vietnam participated in this study. Their age range is from 18 to 20. Most students had learned English as a required subject for six years in high school. The participants were randomly placed in one of two classes: a control group class and an experimental group class. The classes met once a week for forty-five minutes. The data for only 70 participants was included in the data analysis because six students failed to attend all test sessions. One hundred and fifty students of a similar level of English proficiency to the study participants 
(intermediate level) were involved in the pilot of the questionnaire and vocabulary tests. To validate the study, two teachers were invited to administer the tests and mark students' papers.

\section{Procedure}

To reach the research goals in this study, questionnaires, tests, and interviews were used. The questionnaires were used to investigate the participants' motivation in vocabulary learning (see Appendix A). The 18 items on the questionnaire, rated with a five-point Likert Scale (McDonough \& McDonough, 1997), were adapted from the Intrinsic Motivation Inventory (Deci \& Ryan, 1985). The vocabulary test was developed from vocabulary and structures in the English KnowHow Opener course book. The construction of the test followed Hughes' (1989) test specifications, which included recognition and production. This five-part test (see the test sample in Appendix B) was administered to the participants both as a pre-test to examine their vocabulary competence and as a post-test to measure their vocabulary gain. Interviews with nine students from the experimental group were conducted to explore participants' attitudes towards the use of TBL.

The materials used in the current study were seven reading texts from the students' course book English KnowHow Opener (Naber \& Blackwell, 2003). Seven text-based task lessons (see Appendix C) including the three stages of pre-task, task cycle and language focus were generated based on Willis' (1996) framework for TBL.

This experiment was conducted within the twelve-week regular class term. The prequestionnaire was administered to both groups on the first day of class. The participants took the vocabulary pre-test once they completed the pre-questionnaire. The reading lesson was taught to both groups. The difference between the two groups was that the researcher teaching the two classes used a traditional method of teaching vocabulary in the control group while she applied text-based tasks to the experimental group every two weeks. After the experiment was completed (Week 12), the post-questionnaire and the post-test were delivered to both groups at the same time. At Week 12, after the post-test and questionnaire were administered, individual interviews with students from the experimental group were conducted.

\section{Student Motivation}

\section{Findings}

Before the Experiment. The results revealed that the mean difference $(M D=-.00)$ in student motivation to learn vocabulary between the control group $(M=3.58, S D=.26)$ and the experimental group $(M=3.59, S D=.29)$ was extremely small, which indicated that the initial levels of motivation to learn vocabulary between two conditions were similar $(t=-.14, d f=68$, $p=.88$ ). In other words, the two groups were homogeneous in terms of motivation to learn vocabulary at the beginning of the experiment, as shown in Table 1.

\section{Table 1}

\section{Independent Samples T-Test (Pre-Questionnaire)}

\begin{tabular}{ccccccccc}
\hline Questionnaire & Condition & $N$ & $t$ & $d f$ & Mean & Sig. (2-tailed) & MD & $S D$ \\
\hline \multirow{2}{*}{ Pre } & Control & 35 & -.14 & 68 & 3.58 & .88 & -.00 & .26 \\
& Experimental & 35 & & & 3.59 & & & .29 \\
\hline
\end{tabular}

After the Experiment. Table 2 below shows that the mean score of student motivation of the experimental group $(M=3.93, S D=.21)$ was much higher than that of the control group $(M=$ $3.60, S D=.21)$. In addition, the mean difference $(M D=-.32)$ in student motivation to learn 
vocabulary between the two groups after the study was a statistically significant difference $(t=-$ $6.24, d f=68, p=.00)$. These results indicated that the level of student motivation between the two groups after the experiment was significantly different. It was concluded that the experimental group outperformed the control group in terms of motivation to learn vocabulary after the experiment.

Table 2

Independent Samples T-Test (Post-Questionnaire)

\begin{tabular}{ccccccccc}
\hline Questionnaire & Condition & $N$ & $t$ & $d f$ & Mean & Sig. (2-tailed) & MD & $S D$ \\
\hline \multirow{2}{*}{ Post } & Control & 35 & -6.24 & 68 & 3.60 & .000 & -.32 & .21 \\
& Experimental & 35 & & & 3.93 & & & .21 \\
\hline
\end{tabular}

In general, student motivation to learn vocabulary in the control condition before and after the experiment was almost unchanged, whereas the motivation of the experimental condition increased dramatically. Moreover, the mean score for student motivation on the postquestionnaire in the experimental group was statistically higher than that of the control group. Consequently, the experimental group outweighed the control group in terms of student motivation to learn vocabulary at the end of the experiment. Figure 2 illustrates the increase of participant motivation for vocabulary learning.

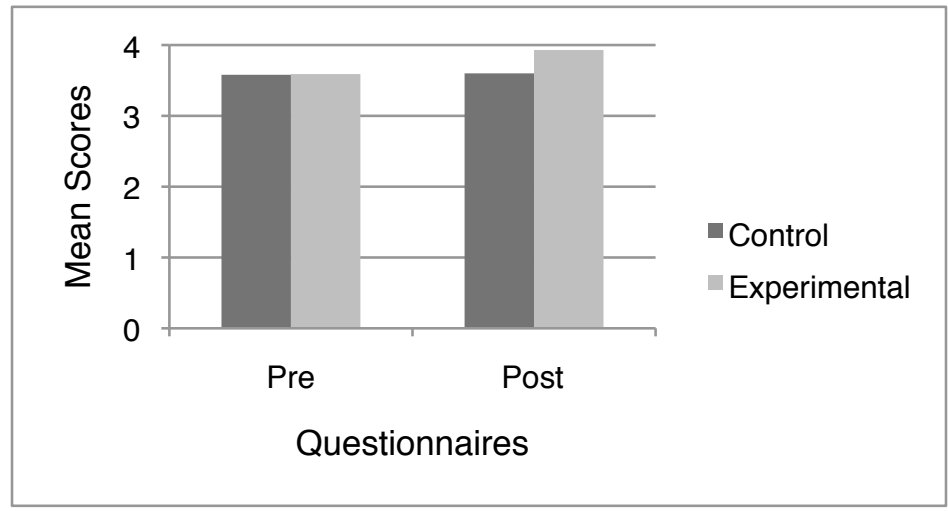

Figure 2. Participants' motivation between and within the control and experimental classes, pre- and post treatment

\section{Students' Vocabulary Achievement}

Before the Experiment. Before the experiment, the mean difference $(M D=.00)$ in learners' vocabulary pre-test scores between the two groups of students was very small, which showed that the initial levels of students' vocabulary competence between the control group $(M=.31$, $S D=.11)$ and the experimental group $(M=.30, S D=.12)$ were very similar. These results indicated that both groups did not differ significantly $(t=.15, d f=68, p=.88)$ in their vocabulary competence. Hence, the homogeneity of the two groups in terms of vocabulary competence was established at the beginning of the experiment, as shown in Table 3.

\section{Table 3}

Independent Samples T-Test of Two-Group Vocabulary Performance (Pre-Test)

\begin{tabular}{ccccccccc}
\hline Test & Condition & $N$ & $t$ & $d f$ & Mean & Sig. (2-tailed) & MD & $S D$ \\
\hline \multirow{2}{*}{ Pre } & Control & 35 & .15 & 68 & .31 & .88 & .00 & .11 \\
& Experimental & 35 & & & .30 & & .12 \\
\hline
\end{tabular}


After the Experiment. The results shown in Table 4 reveal that the mean difference $(M D=-$ $.14)$ in students' vocabulary post-test scores between the two groups is significantly different $(t$ $=-.54, d f=68, p=.00$ ). Performance was much better on the vocabulary post-test in the experiment condition $(M=1.73, S D=.11)$ than in the control condition $(M=1.59, S D=.10)$, which seemed to indicate that the level of vocabulary achievement in the experimental group was much higher than that in the control group after the experiment.

\section{Table 4}

Independent Samples T-Test of Two-Group Vocabulary Performance (Post-Test)

\begin{tabular}{ccccccccc}
\hline Test & Condition & $N$ & $t$ & $d f$ & Mean & Sig. (2-tailed) & MD & $S D$ \\
\hline \multirow{2}{*}{ Post } & Control & 35 & -.54 & 68 & 1.59 & .00 & -.14 & .10 \\
& Experimental & 35 & & & 1.73 & & & .11 \\
\hline
\end{tabular}

Generally, vocabulary achievement in both conditions increased significantly after the experiment, but the vocabulary gain of the experimental group $(M=1.73)$ outweighed that of the control group $(M=1.59)$. Figure 3 displays the vocabulary achievement of both groups.

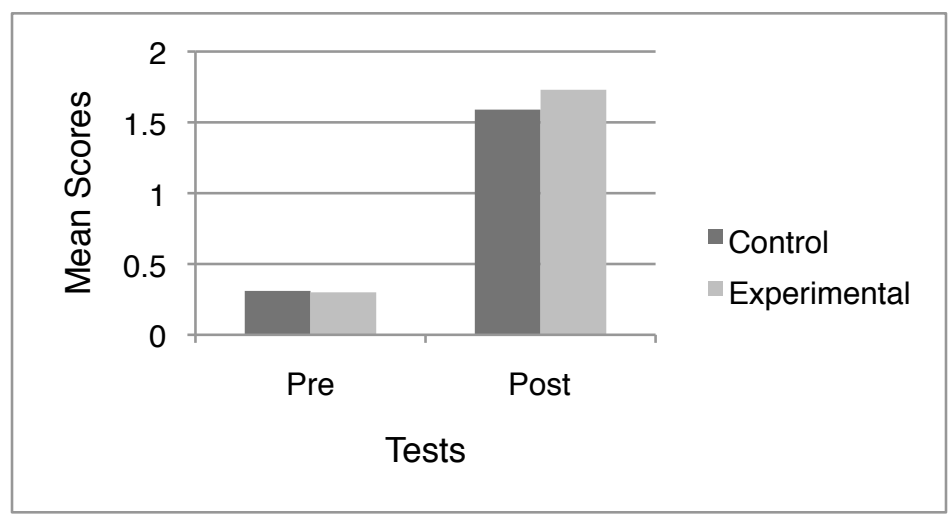

Figure 3. Participants' vocabulary achievement

\section{Participants' Attitudes Towards the Use of Text-Based Tasks}

In Week 12, nine students from the experimental group were interviewed in Vietnamese to investigate their attitudes towards the use of TBL for incidental vocabulary acquisition. Most of the students reported that they preferred TBL to traditional methods of teaching vocabulary and they expected to have such text-based tasks repeated in subsequent semesters. Student 1 , for example, stated, "This is the first time I've experienced this method and done those activities. I find it exciting to learn with this way." (All quotes from students have been translated.) In this quote, the student indicated the value or benefits of text-based tasks being involved in the experiment. Another student stressed the role of small group work through learning vocabulary in context, saying "I like working in groups because each knows one word so the whole group can work out the answers." When asked about the choice between traditional vocabulary learning techniques and task-based learning (text-based tasks), other students mentioned that each student has his or her own idea, enabling the student to contribute to the group. These students not only understood the importance of the text-based tasks, but also highlighted the opportunities to express their own ideas. In general, it could be asserted that students had positive attitudes towards the use of TBL in vocabulary acquisition (see Appendix D). 


\section{Discussion}

The findings indicate that participant motivation to learn vocabulary in the experimental group increased substantially after the experiment. The study suggests that employing TBL with the experimental group considerably promoted student motivation in learning vocabulary. The results support Kavaliauskienè's (2005) finding that students were receptive to task-based learning in English for Specific Purposes (ESP) classes. Specifically, this study reinforces the role of TBL in enhancing student learning suggested by Ruso (2007).

At the end of the experiment, participant motivation to learn vocabulary in the control group was almost the same as at the beginning, whereas student motivation in the experimental group increased sharply (see Figure 2). This finding could be due to the appropriate use of TBL in the classroom. Willis (1996) claimed that TBL provides learners with a wide range of advantages, for example, a comfortable learning environment that allows shy students to overcome stress or fear and speak or have discussions with others. Consequently, students in the experimental group were motivated to do the tasks.

Another factor to explain the increased level of student motivation in the experimental group to learn vocabulary could be the tasks themselves. These text-based tasks were designed to be real, meaningful, and learner-centred (Skehan, 1998), giving students an active role in participation; hence, their motivation increased. One more reason for increased motivation could be that the tasks used with the experimental group were designed to match the factors that promoted intrinsic motivation (Malone \& Lepper, 1987); the text-based tasks usually included some of the seven factors. Learners were highly motivated when working towards personally meaningful goals whose attainment required activity at an intermediate level of difficulty; challenging, but achievable tasks enhanced the motivation of the participants in the experimental group.

Students in both groups improved their vocabulary achievement. However, the mean difference in post-test scores between the two groups is statistically different. The level of vocabulary achievement in the experimental group was much higher than that in the control group. The results imply that TBL significantly improved students' vocabulary achievement. The finding is consistent with that of Joe (1998), who found that tasks related to reading promote incidental vocabulary acquisition and expand vocabulary in EFL classroom contexts. The findings also support de la Fuente's (2006) study that task-based vocabulary lessons have an impact on word retention in second / foreign language learning.

The students' vocabulary achievement in the experimental group improved substantially (see Figure 3) as a result of three reasons. First, it is likely related to the utilisation of the TBL strategy. It was evident that students who did not even use the words, but simply observed the negotiation (Newton, 1995), could remember meaning-negotiated lexical items better than non-negotiated items. Second, the nature of the text-based tasks explained students' vocabulary improvement. According to Jacobs \& Navas (2000), these types of tasks are likely to motivate students to learn a language in a practical way. Third, the text-based tasks were tailored to support the vocabulary acquisition processes, the real steps that were carried out within the classroom, based on Willis' (1996) framework. Figure 4 illustrates these processes. 


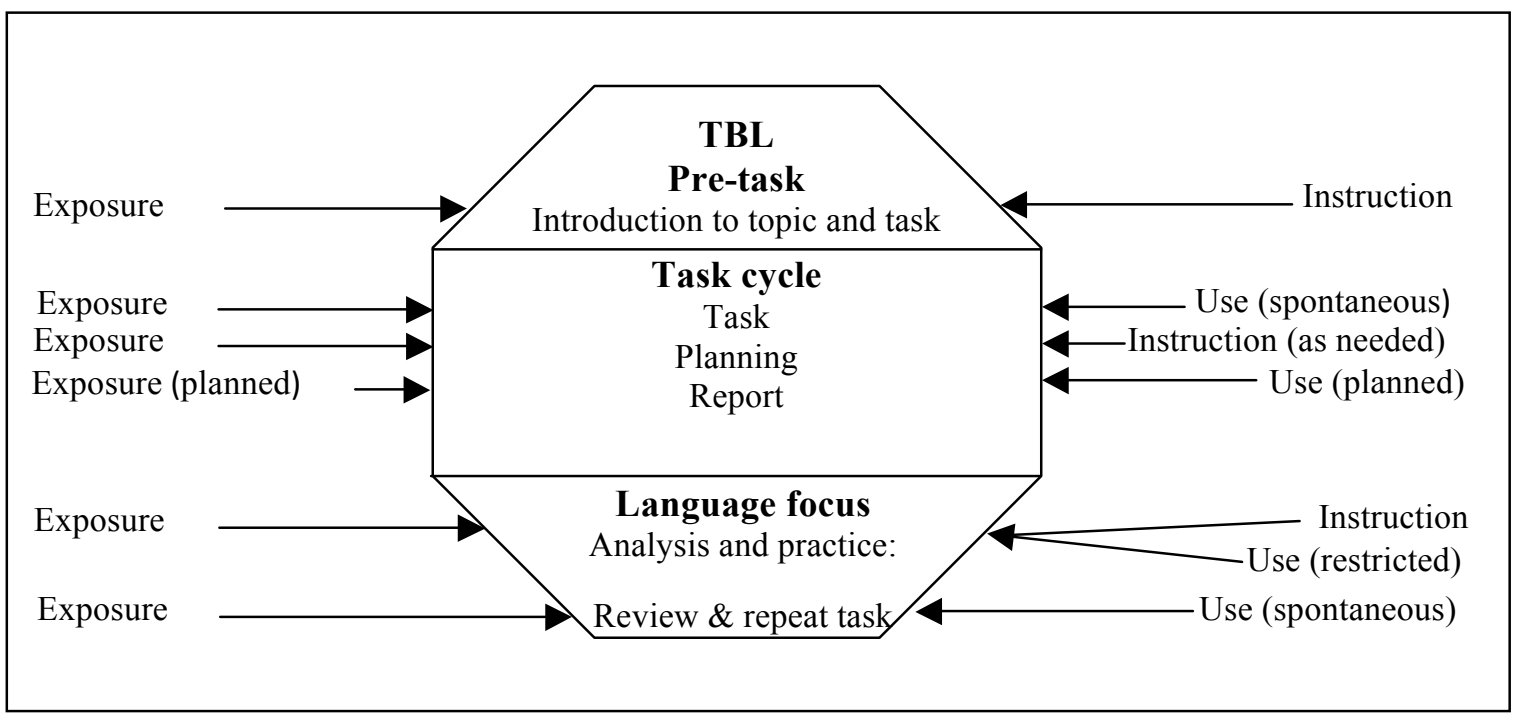

Figure 4. A typical TBL lesson based on Willis' (1996) framework

\section{Conclusion}

The findings have shed new light on the effectiveness of TBL in promoting students' vocabulary. The study may raise teachers' awareness of learners' attitudes towards TBL and, in particular, may offer teachers encouragement to utilise TBL in their practice. The results also provide both teachers and students with insightful perspectives into how TBL plays an important role in the process of teaching and learning vocabulary. These impacts will usher in positive attitudes towards the use of TBL within the context of vocabulary teaching. Significantly, TBL learning may become a promising vehicle for teachers to do further research, optimise the use of teaching resources, and ultimately maximise student learning in vocabulary.

\section{Author Note}

Le Ngoc Thanh, Department of Social Economics, Vinh Long Community College, Vietnam, and Nguyen Buu Huan, Center for Foreign Languages, Can Tho University, Vietnam.

Correspondence concerning this article should be addressed to Le Ngoc Thanh, Department of Social Economics, Vinh Long Community College: 112A Dinh Tien Hoang Street, Ward 8, Vinh Long City, Vietnam, and Nguyen Buu Huan, Center for Foreign Languages, Can Tho University: Campus 2, 3/2 Street, Can Tho City, Vietnam. E-mail: Inthanh@vlcc.edu.vn, nbhuan@gmail.com 


\section{References}

Ahmad, J. (2011). Intentional versus incidental vocabulary learning. Interdisciplinary Journal of Contemporary Research in Business, 3(5), 67-75.

Brophy, J. (2005). Motivating students to learn (2 ${ }^{\text {nd }}$ ed.). Mahwah, NJ: Lawrence Erlbaum.

Bygate, M., Skehan, P., \& Swain, M. (2001). Researching pedagogic language learning, teaching and testing. Harlow, England: Longman.

de la Fuente, M. J. (2006). Classroom L2 vocabulary acquisition: Investigating the role of pedagogical tasks and form-focused instruction. Language Teaching Research, 10(3), 263-295. http://dx.doi.org/10.1191/1362168806/r196oa

DeCarrico, J. S. (2001). Vocabulary learning and teaching. In M. Celce-Murcia (Ed.), Teaching English as a second or foreign language ( ${ }^{\text {rd }}$ ed., pp. 285-299). Boston, MA: Heinle \& Heinle.

Deci, E. L., \& Ryan, R. M. (1985). Intrinsic motivation and self-determination in human behavior. New York, NY: Plenum Press.

Ellis, R. (2003). Task-based language learning and teaching. Oxford, England: Oxford University Press.

Gardner, R. C., \& Lambert, W. E. (1972). Attitudes and motivation in second language learning. Rowley, MA: Newbury House.

Gass, S. (1999). Discussion: Incidental vocabulary learning. Studies in Second Language Acquisition, 21(2), 319-333. http://dx.doi.org/10.1017/S0272263199002090

Jacobs, G. M., \& Navas, E. (2000). The task of teaching task-based language teaching to teachers. The English Teacher, 3(3), 54-64.

Huckin, T., \& Coady, J. (1999). Incidental vocabulary acquisition in a second language. Studies in Second Language Acquisition, 21, 181-193. http://dx.doi.org/10.1017/S0272263199002028

Hughes, A. (1989). Testing for language teachers. Cambridge, England: Cambridge University Press.

İlïn, G., İnözü, J., \& Yumru, H. (2007). Teachers' and learners' perceptions of tasks: Objectives and outcomes. Journal of Theory and Practice in Education. 3 (1), 60-68.

Joe, A. (1998). What effects do text-based tasks promoting generation have on incidental vocabulary acquisition? Applied Linguistics, 19(3), 357-377. http://dx.doi.org/10.1093/applin/19.3.357

Kavaliauskienè, G. (2005). Task-based learning and learning outcomes in the ESP classroom. Studies About Languages, 7.

Lepper, M. R., \& Malone, T. W. (1987). Intrinsic motivation and instructional effectiveness in computer-based education. In R. E. Snow \& M. J. Farr (Eds.), Aptitude, learning and instruction (Vol. 3): Conative and affective process analyses (pp. 255-267). Hillsdale, NJ: Lawrence Erlbaum.

Malone, T. W., \& Lepper, M. R. (1987). Making learning fun: A taxonomy of intrinsic motivation for learning. In R. E. Snow \& M. J. Farr (Eds.), Aptitude, learning and instruction (Vol. 3): Conative and affective process analyses (pp. 223-250). Hillsdale, NJ: Lawrence Erlbaum.

McDonough, J., \& McDonough, S. (1997). Research methods for English language teacher. Arnold.

Naber, T., \& Blackwell, A. (2003). English knowhow opener: Student book. Oxford University Press.

Nation, I. S. P. (2001). Learning vocabulary in another language. Cambridge, England: Cambridge University Press. 
Newton, J. (1995). Task-based interaction and incidental vocabulary learning: A case study. Second Language Research, 11(2), 159-177.

http://dx.doi.org/10.1177/026765839501100207

Nunan, D. (1989). Designing tasks for the communicative classroom. Cambridge, England: Cambridge University Press.

Nunan, D. (2004). Task-based language teaching. Cambridge, England: Cambridge University Press.

Prabhu, N. S. (1987). Second language pedagogy. Oxford, England: Oxford University Press.

Pulido, D. (2004). The relationship between text comprehension and second language incidental vocabulary acquisition: A matter of topic familiarity? Language Learning, 54(3), 469-523. http://dx.doi.org/10.1111/j.0023-8333.2004.00263.x

Richards, J. C., \& Renandya, W. A. (Eds.). (2002). Methodology in language teaching: An anthology of current practice. Cambridge, England: Cambridge University Press.

Richards, J. C., \& Schmidt, R. W. (2002). Longman dictionary of language teaching and applied linguistics ( $3^{\text {rd }}$ ed.). London, England: Longman.

Ruso, N. (2007). The influence of task based learning on EFL classrooms. Asian EFL Journal, 18.

Schmitt, N. (2000). Vocabulary in language teaching. Cambridge, England: Cambridge University Press.

Skehan, P. (1998). A cognitive approach to language learning. Oxford, England: Oxford University Press.

Willis, J. (1996). A framework for task-based learning. Harlow, England: Longman. 


\section{Appendix A}

Intrinsic Motivation Questionnaire (Sample)

Adapted from Deci \& Ryan (1985)

Class: $\quad$ Student Code: $\quad$ Gender: $\square$ Male $\quad \square$ Female

Check $(\checkmark)$ the box that best describes your viewpoint toward each statement.

\begin{tabular}{|c|l|l|l|l|l|l|}
\hline \multirow{2}{*}{ No. } & \multicolumn{2}{|c|}{ Statements } & \multicolumn{3}{c|}{ Scale } \\
\cline { 3 - 7 } & $\begin{array}{c}\text { Strongly } \\
\text { disagree }\end{array}$ & Disagree & No idea & \multicolumn{2}{c|}{ Agree } & $\begin{array}{c}\text { Strongly } \\
\text { agree }\end{array}$ \\
\hline 1. & $\begin{array}{l}\text { I enjoy doing vocabulary tasks very } \\
\text { much. }\end{array}$ & & & & & \\
\hline 2. & It is fun to do vocabulary tasks. & & & & & \\
\hline 3. & $\begin{array}{l}\text { I am relaxed while I am doing } \\
\text { vocabulary tasks. }\end{array}$ & & & & & \\
\hline
\end{tabular}




\section{Appendix B \\ Vocabulary Pre- and Post-Test (Sample)}

Student Code:

Gender: $\square$ Male

Female

Class:

Score:

I. Choose the most appropriate synonym for the underlined word

1. Write down the answer for this question.
a. principle
b. response
c. slave
d. beach

10. Please switch off the television. It's too noisy.
a. turn off
b. make up
c. expect
d. design

II. Circle the letter that is the best answer.

11. Many people can't stop smoking cigarette. It's very
a. extreme
b. spices
c. addictive
d. varying

30. There are a lot of. on radio and TV. Many people don't like them
a. avocado
b. spices
c. variety
d. advertisings

III. Write the correct word to complete its definition. The first letter has been given as a cue 31. U is the best.

40. $\mathrm{T}$ is a kind of musical instrument

IV. Give the opposites of the following words. The first letter of the opposite has been given as a cue.
41. present \# p
50. reach \#f

V. Fill in the blank with a suitable word or phrase that you have learned. The first letter of the word has been given as a cue.

51. Our professor is good at many things. He is a man with many $\mathbf{t}$

60. The USA is a $\mathbf{p}$ country in the world. 


\section{Appendix C \\ A Task-Based Lesson}

TOPIC 1: Cooking in different parts of the U.S.A.

Level: Elementary

Duration: 45 minutes

Objectives: By the end of the lesson, the students will be able to understand new words in context and then compare American dishes and Vietnamese ones

Preparation: Pictures of ham and a hot dog; handouts

\begin{tabular}{|c|c|c|c|}
\hline Stage & Aims & \begin{tabular}{|l} 
Procedure \\
\end{tabular} & Interaction \\
\hline \multirow[t]{3}{*}{ Pre-task } & $\begin{array}{l}\text { Students (Ss) are } \\
\text { introduced to the topic } \\
\text { with Activity } 1 .\end{array}$ & $\begin{array}{l}\text { Ss discuss } 3 \text { questions (Activity 1) then share } \\
\text { ideas. Teacher (T) shows pictures of ham } \\
\text { and a hot dog. }\end{array}$ & pairs \\
\hline & \multirow{2}{*}{\begin{tabular}{|l|} 
Ss identify topic \\
language with Activity \\
2.
\end{tabular}} & $\begin{array}{l}\text { Ss work out word meanings in contexts } \\
\text { (Activity 2). }\end{array}$ & whole class \\
\hline & & $\begin{array}{l}\text { T models the pronunciation of new words. } \\
\text { Students repeat. }\end{array}$ & $\begin{array}{l}\text { whole class } \\
\text { groups }\end{array}$ \\
\hline Task cycle 1 & $\begin{array}{l}\text { Ss are exposed to } \\
\text { English. }\end{array}$ & & \\
\hline Task 1 & $\begin{array}{l}\text { Ss scan the text and } \\
\text { complete Activity } 3 .\end{array}$ & $\begin{array}{l}\text { Ss scan the text and fill in the map (Activity } \\
3 \text { ). }\end{array}$ & groups \\
\hline Planning 1 & $\begin{array}{l}\text { Ss write down } \\
\text { answers. }\end{array}$ & $\begin{array}{l}\text { Ss summarise answers in writing and role } \\
\text { play the report. T may facilitate their } \\
\text { answers. }\end{array}$ & groups \\
\hline Report 1 & $\begin{array}{l}\text { Ss report answers to } \\
\text { class. }\end{array}$ & $\begin{array}{l}\text { Some pairs report to class. Others listen and } \\
\text { check the answers. Ss ask questions and T } \\
\text { provides feedback. }\end{array}$ & whole class \\
\hline $\begin{array}{l}\text { Task cycle } 2 \\
\text { Task } 2\end{array}$ & $\begin{array}{l}\text { Ss use English. } \\
\text { Ss read the text and do } \\
\text { Activity } 4 \text {. }\end{array}$ & $\begin{array}{l}\text { Ss reread the text and complete the chart } \\
\text { (Activity 4). }\end{array}$ & groups \\
\hline Report 2 & $\begin{array}{l}\text { Ss tell the class their } \\
\text { answers. }\end{array}$ & $\begin{array}{l}\text { Some pairs report to class. Others listen and } \\
\text { check the answers. Ss ask questions and T } \\
\text { gives feedback. }\end{array}$ & whole class \\
\hline $\begin{array}{l}\text { Language } \\
\text { focus }\end{array}$ & $\begin{array}{l}\text { Ss analyse and } \\
\text { practice English by } \\
\text { doing Activity } 5 .\end{array}$ & $\begin{array}{l}\text { Ss categorise new words in Task } 2 \text { according } \\
\text { to their parts of speech and read them } \\
\text { (Activity 5). T may correct their } \\
\text { pronunciation. }\end{array}$ & groups \\
\hline Analysis 1 & $\begin{array}{l}\text { Ss define parts of } \\
\text { speech of new words. }\end{array}$ & $\begin{array}{l}\text { Ss select new words and give Vietnamese } \\
\text { meanings. } \\
\text { T may give feedback. }\end{array}$ & $\begin{array}{l}\text { pairs } \\
\text { whole class }\end{array}$ \\
\hline Analysis 2 & $\begin{array}{l}\text { Ss analyse word } \\
\text { meaning and identify } \\
\text { synonyms by } \\
\text { completing Activity } 6 .\end{array}$ & $\begin{array}{l}\text { Ss choose the synonyms of the words on the } \\
\text { left (Activity 6). } \\
\text { T may give feedback. }\end{array}$ & $\begin{array}{l}\text { groups } \\
\text { whole class }\end{array}$ \\
\hline Practice 1 & $\begin{array}{l}\text { Ss compare } \\
\text { Vietnamese and } \\
\text { American dishes using } \\
\text { Activity } 7 .\end{array}$ & $\begin{array}{l}\text { Ss compare Vietnamese and American } \\
\text { dishes using given categories, then tell the } \\
\text { class (Activity 7). }\end{array}$ & groups \\
\hline
\end{tabular}




\section{Appendix D}

Extracts from Student Interview Transcripts (English Translation)

\begin{tabular}{|l|l|}
\hline \multicolumn{1}{|c|}{ Questions } & \multicolumn{1}{c|}{ Interviewees' Opinions } \\
\hline $\begin{array}{l}\text { How do you feel } \\
\text { about the use of } \\
\text { task-based } \\
\text { learning in class? }\end{array}$ & $\begin{array}{l}\text { "This is the first time I experience this method and do those activities. I find it } \\
\text { exciting to learn with this way." (S1, S4) } \\
\text { "I like doing those activities, especially working in groups to find out the answers." } \\
\text { (S3, S8) } \\
\text { "It is interesting to compare my group's answer to those of others." (S4, S9) } \\
\text { "I like this learning atmosphere very much because I feel the time passes quickly. I } \\
\text { am not tired and bored and I don't think the time is over." (S5, S6, S7) } \\
\text { "I am not used to this way of learning. I feel embarrassed."(S8) }\end{array}$ \\
\hline $\begin{array}{l}\text { If you were given } \\
\text { the choice } \\
\text { between the } \\
\text { traditional } \\
\text { vocabulary } \\
\text { learning } \\
\text { techniques and } \\
\text { task-based } \\
\text { learning, which } \\
\text { would you } \\
\text { prefer? Why? }\end{array}$ & $\begin{array}{l}\text { "I know a lot of new words with this method." (S1, S5) } \\
\text { "I think those tasks are very useful. I would like to learn with this method next } \\
\text { semester." (S3, S6, S7) } \\
\text { "Those tasks include both old and new vocabulary, so I can guess the meanings of } \\
\text { new words based on the old ones." (S1, S4) } \\
\text { "I choose the new method because I can remember new words immediately. It } \\
\text { "I like working in groups because each knows one word so the whole group can } \\
\text { work out the answers." (S2, S3) } \\
\text { "Each student has his/her own idea so they can contribute to the group."(S7, S9) } \\
\text { "This method is interesting. Such activities help us to work out word meaning and } \\
\text { we remember them longer." (S2, S5) } \\
\text { "Thanks to those activities, we know about some American styles of cooking. They } \\
\text { are interesting because they are not what we expected." (S9) } \\
\text { "I like this method because it helps us become more dynamic. We speak more } \\
\text { when doing the tasks and we feel less nervous in front of the class." (S1, S3) } \\
\text { "I like the traditional vocabulary learning because I have a lot of difficulties with } \\
\text { this new method. It is clearer if the teacher gives the answers. Guessed meanings of } \\
\text { words are ambiguous. I get frustrated because of many new words. I do not catch } \\
\text { up with my friends. I am slow to work out the answers. I like working with the next } \\
\text { person because I do not like to move." (S8) }\end{array}$ \\
\hline
\end{tabular}

Note. $\mathrm{S}=$ Student 